\title{
Produksi Benih Sintetik Tanaman Moringa oleifera
}

\author{
Chusnul Eka Safitri Himayani dan Wirdhatul Muslihatin \\ Departemen Biologi, Fakultas Ilmu Alam, Institut Teknologi Sepuluh Nopember (ITS) \\ e-mail:w_muslih@bio.its.ac.id
}

\begin{abstract}
Abstrak-Perbanyakan tanaman Moringa oleifera secara generatif cukup sulit dilakukan karena kemampuan perkecambahan bijinya rendah kelangsungan hidupnya rendah, pertumbuhan membutuhkan waktu yang lama dan kurangnya metode perbanyakan secara vegetatif. Salah satu alternatif untuk mengatasi kendala tersebut adalah dengan melakukan perbanyakan tanaman secara vegetatif melalui pendekatan bioteknologi yaitu teknik kultur in Vitro dan teknik enkapsulasi yang dapat menghasilkan benih sintetik. Tujuan dari penelitian ini mengetahui tahapan yang dilakukan pada proses produksi benih sintetik tanaman Moringa oleifera. Tahapan yang dilakukan pada penelitian ini adalah induksi kalus embriogenik dalam medium MS + NAA 1 mg/L + Kinetin 1 mg/L. Kemudian kalus embriogenik yang didapatkan akan dipindahkan ke medium maturasi BAP $3 \mathrm{mg} / \mathrm{L}$. Pada tahap maturasi terjadi perkembangan kalus embriogenik menjadi embrio somatik. Embrio somatik yang didapatkan akan dienkapsulasi menggunakan Alginat dengan konsentrasi 4\% dan diletakkan di CaCl2 konsentrasi $75 \mathrm{mM}$, saat benih sudah mengeras dibilas menggunakan aquades. Benih yang dhasilkan memiliki warna bening dan embrio berwarna putih kekuningan dengan diameter berkisar 5,2 - 5,7 mm dan memiliki berat basah berkisar 90 280 miligram.
\end{abstract}

Kata Kunci-Benih sintetik, in Vitro, Kalus embriogenik, Moringa oleifera.

\section{PENDAHULUAN}

$\mathrm{K}$ ELOR Moringa oleifera L. merupakan tumbuhan dari suku Moringaceae. Daunnya berbentuk bulat lonjong dan ukurannya yang kecil tersusun rapi pada sebuah tangkai, biasanya dimasak sebagai sayur, untuk pengobatan dan untuk menjaga kesehatan. Daun $M$. oleifera mengandung potasium tiga kali lipat daripada pisang, mengandung kalsium empat kali lipat lebih banyak daripada susu, memiliki vitamin $\mathrm{C}$ tujuh kali lipat daripada jeruk dan mengandung vitamin A empat kali lipat daripada wortel [1]. M. oleifera digunakan untuk menjaga kesehatan karena ekstrak daunnya menunjukkan aktivitas antimikroba dan antifungal serta aktivitas antikanker [2].

Pemanfaatan $M$. oleifera yang luas menyebabkan kebutuhan tanaman kelor semakin meningkat. Pemenuhan kebutuhan akan kelor mengalami kendala salah satunya perbanyakan tanaman $M$. oleifera yang masih dilakukan secara konvensional yaitu melalui biji (generatif). Perbanyakan tanaman $M$. oleifera secara generatif cukup sulit untuk dilakukan karena kemampuan perkecambahan (viabilitas) bijinya rendah, kelangsungan hidupnya rendah, pertumbuhan membutuhkan waktu yang lama dan kurangnya metode perbanyakan secara vegetatif [2].

Salah satu alternatif untuk mengatasi kendala tersebut adalah dengan melakukan perbanyakan tanaman secara vegetatif melalui pendekatan bioteknologi yaitu teknik kultur in Vitro [3]. Tahap penelitian kultur in Vitro mulai dari eksplanting, pembentukan kalus sampai pada perkecambahan. Sel - sel kalus akan berkembang menjadi embrio melalui tahap - tahap morfologi yang khas tanpa melalui fase gamet. Perkembangan embrio somatik melalui tahap embrio disebut embriogenesis somatik [4].

Kalus dan embriogenesis somatik yang terbentuk masih rentan terhadap kontaminasi apabila disimpan dalam waktu yang relatif lama. Oleh karena itu, upaya perlindungan dilakukan dengan menggunakan teknik enkapsulasi yang dapat menghasilkan benih sintetik. Benih sintetik dapat memberi keuntungan antara lain penyimpanan yang tahan lama, mempermudah distribusi atau penyebaran, serta dapat melindungi benih dari penyakit [5].

Teknologi Benih sintetik telah diterapkan pada berbagai macam bahan tanaman seperti kalus, embrio somatik, akar bermbut (hairy roots), pucuk tunas, tunas aksiler, dan benih biasa dari banyak jenis tanaman [6]. Ekplan pada benih sintetik akan berada di dalam mantel (kapsul), sehingga sifatnya mirip dengan benih zigotik. Mantel tersebut berperan sebagai endosperma yang mengandung sumber karbon, nutrisi, dan zat pengatur tumbuh (ZPT) [7].

Benih sintetik dibuat dengan pendekatan enkapsulasi (alginasi) dengan cara membungkus embrio somatik dengan natrium alginat yaitu sejenis gel yang dapat diperkaya dengan hara, zat pengatur tumbuh, mikroorganisme yang bersifat simbiosis. Alginat adalah polisakarda yang banyak terdapat pada dinding sel dari spesies ganggang coklat. Alginat juga berfungsi sebagai bahan antibakteri, hal ini sesuai dengan hasil penelitian yang dilakukan oleh [8] bahwa bakteri tidak dapat tumbuh pada membrane alginat dengan adanya daerah zonasidaerah zona bening di sekitar membrane alginate.

Penelitian ini bertujuan untuk mengetahui tahapan yang dilakukan pada proses produksi benih sintetik tanaman Moringa oleifera.

\section{METODOLOGI}

\section{A. Sterilisasi Eksplan Daun}

Eksplan yang digunakan adalah daun $M$. oleifera. Sterilisasi dilakukan dalam dua tahapan, yaitu sterilisasi diluar LAF dan sterilisasi didalam LAF. Sterilisasi diluar LAF, daun dicuci dengan air mengalir selama 10 menit, daun direndam pada larutan surfaktan selama 10 menit, daun dicuci dengan air mengalir selama 5 menit. Sterilisasi di dalam LAF, daun direndam pada larautan antifungal (Propinap 70\%) selama 10 menit, daun direndam pada larutan $\mathrm{NaOCl}$ selama 2 menit, daun direndam dalam alkohol $96 \%$ selama 3 menit, kemudian daun direndam dengan aquades steril selama 2 x 5 menit. 


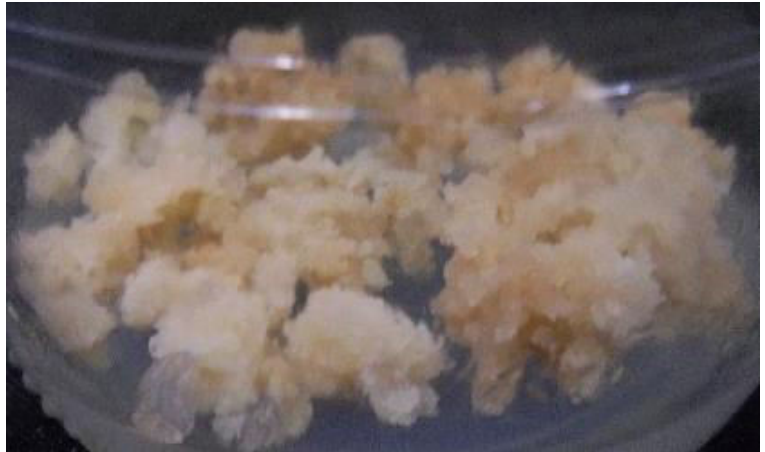

Gambar. 1. Kalus M. oleifera berwarna putih kekuningan (Dokumentasi pribadi, 2017).

\section{B. Induksi Kalus Embriogenik}

Medium yang digunakan untuk menginduksi pertumbuhan kalus adalah medium Murashinge and Skoog (MS) ditambah 1 $\mathrm{mg} / \mathrm{L}$ NAA dan $1 \mathrm{mg} / \mathrm{L}$ kinetin [9] dengan penambahan sukrosa $30 \%$. Medium dikondisikan dalam $\mathrm{pH}$ 5,8 dengan menambahkan $1 \mathrm{~N} \mathrm{NaOH}$ atau $1 \mathrm{~N} \mathrm{HCl}$, kemudian medium disterilisasi menggunakan autoclave pada suhu $121^{\circ} \mathrm{C}$ selama 20 menit dengan tekanan 1,2 atm. Eksplan diinokulasi ke medium di ruang LAF dalam keadaan steril. Kultur disimpan pada ruang dengan suhu $20-25^{\circ} \mathrm{C}$ sampai terbentuk kalus embriogenik.

\section{Maturasi Embriosomatik}

Kalus embrogenik yang terbentuk disubkultur pada medium MS dengan penambahan BAP sebanyak 3mg.L, disiman pada ruang dengan suhu $20-25^{\circ} \mathrm{C}$. Pada tahap ini mulai diamati perkembangan embrio somatik dan akan dienkapsulasi

\section{Teknik Enkapsulasi}

Sodium alginat $4 \%$ ditambah dengan $0,3 \mathrm{mg} / \mathrm{L}$ NAA dan 3 $\mathrm{mg} / \mathrm{L}$ BAP pada medium MS cair bebas kalsium yang mengandung 3\% sukrosa. Enkapsulasi dilakukan dengan pencampuran yang lembut embrio pada gel sodium alginat dan MS. Potongan kalus dimasukkan ke dalam campuran sodium alginat dan MS cair lalu diambil menggunakan pipet plastik steril sekali pakai dengan posisi semua bagian embrio tertutupi oleh sodium alginat kemudia dimasukkan kedalam larutan $75 \mathrm{mM} \mathrm{CaCl}_{2}$ selama 15 hingga 20 menit, kemudian butiran butiran tersebut direndam dalam aquades untuk menghilangkan residu kalsium klorida.

\section{PEMBAHASAN}

Eksplan yang digunakan untuk pembentukan kalus embriogenik adalah daun muda. Kalus akan tumbuh pada bagian eksplan daun yang terpotong dan telah disterilkan, hal ini dikarenakan rangsangan luka yang mampu menyebabkan kesetimbangan pada dinding sel berubah arah, sebagian protoplas mengalir keluar sehingga mulai terbentuk kalus embriogenik [10]. Kalus embriogenik yang terbentuk secara visual menampilkan warna yang hampir sama yaitu putih kekuningan dengan struktur kalus yang remah (friable).

Kalus embriogenik yang terbentuk kemudian akan dipindahkan kedalam medium maturasi. Maturasi adalah tahap perkembangan kalus embriogenik menjadi embrio somatik

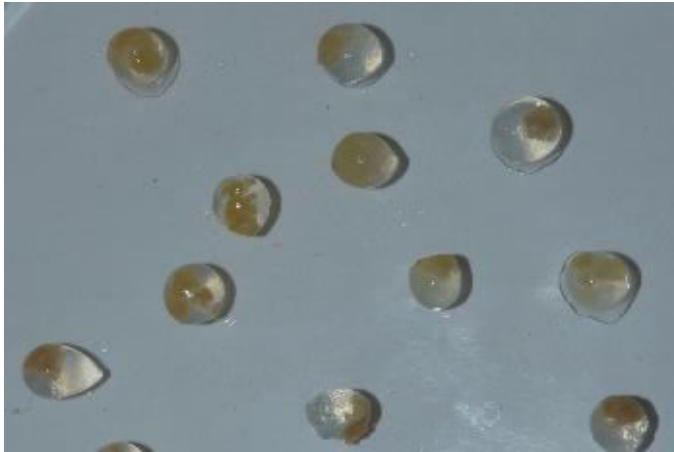

Gambar. 2. Benih sintetik M.oleifera (Dokumentasi Pribadi, 2017).

[11]. Tahap perkembangan kalus embriogenik ini merupakan tahap perkembangan dari fase globular, fase hati, fase torpedo dan fase kotiledon. Embrio somatik yang dihasilkan akan dienkapsulasi menggunakan alginat dengan konsentrasi $4 \%$. Alginat merupakan salah satu hidrogel yang paling tepat dalam pembuatan benih sintetik karena diperkaya hara, zat pengatur tumbuh, mempunyai daya toksisitas rendah, biaya rendah, tidak terlalu lengket, cepat menggumpal dan mempunyai sifat biokompatibilitas [12]. Alginat dengan konsentrasi $4 \%$ merupakan konsentrasi yang paling tepat untuk perkecambahan benih sintetik. Alginat yang memiliki konsentrasi terlalu tinggi akan menyebabkan benih yang dihasilkan terlalu keras, sehingga menghambat kemampuan embrio untuk berkecambah. Sesuai dengan pernyataan [13] bahwa kondisi benih yang sangat padat mempengaruhi daya hidup embrio dalam benih karena kondisi tersebut tidak mendukung pertumbuhan dan perkembangan embrio selanjutnya. Kekerasan yang tinggi dalam benih diduga akan menyebabkan lingkungan menjadi anaerobik, selanjutnya akan menghambat respirasi, dan terhambatnya laju respirasi akan menghambat proses perkecambahan benih.

Proses pembuatan benih sintetik diawali dengan pengambilan larutan alginat $4 \%$ menggunakan pipet tetes, kemudian bulb pada pipet ditekan secara perlahan. Ketika larutan alginte keluar dari ujung pipet segera bagian kalus embrio somatik yang akan dienkapsulasi dimasukkan ke dalam tetesan alginate pada ujung pipet menggunakan pinset secara cepat dan tepat hingga seluruh bagian eksplan terbungkus. Kemudian bulb pipet ditekan kembali secara perlahan hingga alginate pada ujung pipet menetes dan jatuh pada larutan $75 \mathrm{mM} \mathrm{CaCl} 2$. Selanjutnya benih sintetik yang telah mengalami pengerasan dikeluarkan darilarutan $75 \mathrm{mM}$ $\mathrm{CaCl} 2$ dan direndam kedalam aquades. Proses pengerasan disebabkan karena terjadinya pertukaran ion $\mathrm{Na}^{+}$dari $\mathrm{Na}-$ alginat dengan $\mathrm{Ca}^{+}$ketika diteteskan ke dalam larutan $\mathrm{CaCl}_{2}$ membentuk $\mathrm{Ca}$ alginate. Banyaknya ion $\mathrm{Na}+$ yang bertukar dengan ion $\mathrm{Ca}^{+}$menentukan tingkat kekerasan kapsul. Kapsul yang terbentuk diharapkan cukup padat agar tidak mudah terjadi kebocoran [14].

$$
2 \mathrm{Na} \mathrm{Alg}_{(\mathrm{aq})}+\mathrm{Ca}^{2+}{ }_{(\mathrm{aq})} \longrightarrow \mathrm{Ca}(\mathrm{Alg}) 2_{(\mathrm{s})}+2 \mathrm{Na}^{+}{ }_{(\mathrm{aq})}
$$

Karakteristik benih sintetik yang dihasilkan adalah benih mempunyai diameter berkisar 5,2-5,7 $\mathrm{mm}$ dengan warna bening dan tampak warna embrio putih kekuningan. 
Benih sintetik yang sudah diukur diameternya kemudian ditimbang untuk mengetahui berat basah awal benih. Benih yang sudah dihasilkan mampu untuk disimpan dalam jangka waktu 1 tahun tanpa mengurangi viabilitas dan vigoritas benih. Selain itu benih dapat ditanam pada medium perkecambahan dengan komposisi ZPT yang sesuai. Selanjutnya setelah benih mampu berkecambah maka selanjutnya akan dipindahkan ke medium aklimatisasi supaya mampu untuk tumbuh dan berkembang dengan baik. Berat basah awal benih berkisar 90 -280 miligram.

\section{KESIMPULAN}

Kesimpulan penelitian ini adalah tahapan yang dilakukan untuk proses produksi benih sintetik adalah induksi kalus embriogenik dengan menggunakan medium NAA 1 ppm dan kinetin $1 \mathrm{ppm}$. Kemudian kalus embriogenik yang didapatkan akan dipindah ke medium maturasi untuk membentuk embrio somatik. Embrio somatik yang didapatkan akan dilakukan teknik enkapsulasi atau pembungkusan eksplan menggunakan alginat konsentrasi $4 \%$ dan kemudian diletakkan pada larutan $\mathrm{CaCl} 2$ konsentrasi $75 \mathrm{Mm}$ selama 15 - 20 menit. Benih akan mengeras dan direndam kedalam aquades. Benih yang sudah dihasilkan mampu disimpan dalam jangka waktu 1 tahun.

\section{DAFTAR PUSTAKA}

[1] F. Anwar, L. Said, and M. Gilani., "Moringa oleifera a Food Plant with Multiple Medicinal Uses," Phyther. Res., vol. 21, pp. 17-25, 2017.

[2] B. N. Devendra, P. Talluri, and N. Srinivas, "Callus Induction and Somatic Embryogenesis of Moringa oleifera Lam an anti-radiation Plant," J. Agric. Technol., vol. 8, no. 6, pp. 1953-1963.

[3] D. F. Wetherell, Plant Tissue Culture Series. New Jersey: Publishing Group Inc, 2008 